\title{
FISCAL AUSTERITY POLICY IMPACT ON WELFARE
}

\section{Romina Pržiklas Družeta, Marinko Škare}

(1) Senior Assistant Lecturer, Faculty of Economics and Tourism "Dr. Mijo Mirković", Juraj Dobrila University of Pula (2) Full Professor, Ph.D., Faculty of Economics and Tourism "Dr. Mijo Mirković", Juraj Dobrila University of Pula

\section{Romina Pržiklas Družeta}

Senior Assistant Lecturer, Faculty of Economics and Tourism "Dr. Mijo Mirković" Pula, Juraj Dobrila University of Pula, Croatia, rprzik@unip.hr

Article info

Paper category: Review paper Received: $17 \cdot 4 \cdot 2017$. Accepted: $27 \cdot 4 \cdot 2017$. JEL classification: D81, D87

This work has been fully supported by the Croatian Science Foundation under the project number 948 Modelling Economic Growth - "Advanced Sequencing and Forecasting Algorithm"

"Any opinions, findings and conclusions or recommendations expressed in this material are those of the author(s) and do not necessarily reflect the views of Croatian Science Foundation" 


\begin{abstract}
The ongoing global financial and economic crisis has caused a dramatic fall in growth, increased deficit, higher unemployment rates and strong price fluctuations. To achieve a balanced budget and reduce the national debt, the most of the national government have sacrificed the employment - one of the main indicators that reflect societies' well-being and implemented fiscal austerity policy. The aim of this paper is to contribute to the literature on this topic and assess the short analysis of fiscal consolidation. Despite the ongoing debate and numerous studies no consensus about whether and when austerity is likely to be beneficial has been achieved. Further, there are still open issues to understand the impact of austerity on poverty and welfare because of the difficulty of defining poverty and welfare also. The main conclusion is that the emphasis should be placed on correctly defining austerity methodology in a broader economic and social context.
\end{abstract}

\title{
Keywords:
}

Fiscal austerity, Economic growth, Welfare, Sustainability 


\section{INTRODUCTION}

To achieve the long term sustainable growth, we cannot separate social and economic context of fiscal sustainability.

The sustainability of fiscal policy in a world of financial turmoil has become an important issue in the economy. Interest rates on government debt rose dramatically and Europe after more than five decades faces again with rising public debt and high budget deficit. Concerns about fiscal imbalance have implied a shift from fiscal stimulus to austerity. To achieve a balanced budget and reduce the national debt, the national government has sacrificed the employment - one of the main economic indicators that reflect societies' well-being. Cutting social security, health care, spending on education, has negatively affected economic growth, poverty and social stability especially in weaker member states. Further, significant variation in economy between the EU's member states have followed different paths to austerity. Despite diversity of national economies fiscal tightening became an almost universal recommendation and implemented policy.

Although many academic researchers have acknowledged a need for greater understanding in these area, see study of Alesina and Perotti (1995), Alesina et al. (1998), Alesina and Ardagna (1998, 2010), Blanchard and Perotti (2002), Wilhelm and Fiestas (2005), Arestis and Pelagridis (2010), Chang (2011), Crotty (2012), Calcagno (2012), Konzelman (2012), Blyth (2013), Galbraith (2014), Branas (2015), Shakina and Barajas (2014) consensus about austerity effects and consequences is still missing.

Further, there are still complications to define the impact of austerity on poverty and welfare because of the difficulty of defining poverty and welfare also. Consequently, we have incomplete picture and obstacle for growth and development.

Since structural adjustment policies have high social costs (have depressed employment, have led to large migration, have increased the cost of health care, education and other elements of well-being) the critical challenge is how to achieve public debt sustainability and decrease unemployment, poverty and inequality at the same time.

The purpose of this study is to analyze social and economic context link to sustainable growth. The answer can help policy maker on deciding if/when should governments undertake austerity policy. While there is no clear answer to the question, it may be useful to review recent research and analyze the moral hazard and the credibility of "belt tightening."

This paper has four parts. Firstly, it reviews the extant literature, then data analysis are presented and discussed. The paper concludes with a discussion of theoretical and statistical implications and directions for further research. 


\section{LITERATURE REVIEW}

The central theme of these article has received extensive attention in the theoretical Perotti (1996), Chang (2011), Konzelman (2012), Krugman (2012), Crotty (2012), Stiglitz (2013), Galbraith (2014) and empirical literature Alesina et al. (1998), Blanchard and Perotti (2002), Alesina and Ardagna (1998, 2010), Matsaganis and Leventi (2014).

For example Perotti 1996, Alesina and Ardagna 1998, 2010, Romer and Romer 2010 , found out that fiscal adjustments based on spending cuts or spending-based consolidation compare with fiscal adjustment based on tax, are more efficient in reducing public debt and led to economic growth. In contrast, Chang 2011, Krugman 2012, Galbraith 2014, Blyth 2013, Calcagno 2012, pointed out that more fiscal adjustment will only worsen the downturn, and that austerity is a dangerous idea and it is not a solution. Further, Auerbach and Gorodnichenko 2012 pointed out that fiscal consolidation has adverse effect on the economy during a recession than during an expansion.

Despite the growing literature, there is a lack of empirical investigation on defining the methodology of austerity especially in defining austerity methodology which will implement economic and social context.

Krugman (2012; 232) noted: "Anyway, the point is that out the question of how economy works should be settled on the basis of evidence, not prejudice."

Whereas there are conflicting points of view in attempt to answer the question "Are more/less government spending or tax increases or decreases more effective in reducing public debt and less harmful for economic growth and development" a chronological review of previous theoretical research and empirical studies are presented in Table 1. and Table 2.

Table 1.: Theoretical Studies on Fiscal Austerity

\begin{tabular}{|l|r|r|}
\hline YEAR & AUTHOR & THEORETICALAPPROACH \\
\hline 1996 & Perotti, R. & $\begin{array}{r}\text { Fiscal consolidation in Europe } \\
2005\end{array}$ \\
2008 & Wilhelm, V., Fiestas, I. & $\begin{array}{r}\text { Exploring the link between public spending } \\
\text { and poverty reduction; (see more review of } \\
\text { recent literature p. 24.) }\end{array}$ \\
2010 & Minsky, H.P. & $\begin{array}{r}\text { Stabilizing an Unstable Economy } \\
2010\end{array}$ \\
2010 & Jayadev, A. Konczal, M. & The right time for austerity \\
2011 & Pollin, R. & Politics of austerity \\
2011 & Arestis, P. Pelagridis, T. & Austerity Policies in Europe \\
2011 & Kitrich, D., Knedlik, T., Lindner, A. & Global financial crisis \\
2011 & Chartin, R., Tyler, P. & Chang, H.J. \\
\end{tabular}




\begin{tabular}{|c|c|c|}
\hline YEAR & AUTHOR & THEORETICALAPPROACH \\
\hline 2011 & Kitromilides, Y. & $\begin{array}{l}\text { Deficit reduction, the age of austerity, and the } \\
\text { paradox of insolvency }\end{array}$ \\
\hline 2011 & Fontana, G., Sawyer, M. & $\begin{array}{r}\text { Fiscal austerity; lessons from recent events in } \\
\text { the British Isles }\end{array}$ \\
\hline 2012 & Konzelman, S. & The Economics of Austerity \\
\hline 2012 & $\begin{array}{r}\text { Mc Kee, M., Karanikolos, M, Belcher, P., } \\
\text { Stucker, D. }\end{array}$ & The human cost of austerity \\
\hline 2012 & Crotty, J. & Austerity war \\
\hline 2012 & Calcagno, A. & Austerity policies \\
\hline 2012 & Romer, C. & $\begin{array}{r}\text { Lessons and policy implications of fiscal } \\
\text { policy }\end{array}$ \\
\hline 2012 & Hannsgen, G., Papadimitrou, D.B. & Fiscal traps after the Eurozone crisis \\
\hline 2012 & Krugman, $\mathrm{P}$. & The Effects of Government Spending \\
\hline 2013 & Blyth, M. & Austerity, The history of a dangerous idea \\
\hline 2013 & Stuckler, D., Basu, S. & The human cost of austerity \\
\hline 2013 & Blyth, M. & The History of a Dangerous Idea \\
\hline 2013 & Stiglitz, J. & $\begin{array}{r}\text { The Battle of the budget; The history of the } \\
\text { deficit }\end{array}$ \\
\hline 2014 & Antokakis, N. Collins, A. & The human cost of austerity \\
\hline 2014 & Palley, T. & Europe's financial crisis \\
\hline 2014 & Galbraith, J. K. & The European Crisis \\
\hline 2014 & Edmiston, D. & $\begin{array}{r}\text { Financial Sustainability of Welfare Reform } \\
\text { in Europe (convergence in responses to } \\
\text { economic crisis) }\end{array}$ \\
\hline 2014 & Overmans, J.F.A. & $\begin{array}{r}\text { Current austerity practices; successes } \\
\text { and failures }\end{array}$ \\
\hline 2014 & Hein, E. and Truger, A. & $\begin{array}{r}\text { Fiscal Policy and Rebalancing } \\
\text { in the Euro Area }\end{array}$ \\
\hline 2015 & Branas et.al. & The human cost of austerity \\
\hline 2015 & Škare, M., Pržiklas Družeta & Fiscal Austerity Versus growth in Croatia \\
\hline $\begin{array}{l}2011, \\
2012\end{array}$ & Arestis, $P$. & Fiscal policy: a strong macroeconomic role \\
\hline
\end{tabular}

Source: Authors' review of the literature 
Table 2.: Empirical Studies on Fiscal Austerity

\begin{tabular}{|c|c|c|}
\hline YEAR & AUTHOR & RESULTS \\
\hline 1995 & Alesina, A., Perotti, R. & $\begin{array}{r}\text { This paper considers budget expansions and } \\
\text { adjustments in OECD countries in the last } \\
\text { three decades. They found out that different } \\
\text { types of governments show different degrees } \\
\text { of success at implementing successful fiscal } \\
\text { adjustment. }\end{array}$ \\
\hline 1998 & Alesina, Perotti, Tavares & $\begin{array}{l}\text { They reexamined (using data from nineteen } \\
\text { countries in the OECD) the economic and } \\
\text { political effects of fiscal adjustments. Their } \\
\text { results indicate that governments that are } \\
\text { willing to "bite the bullet" and persist in } \\
\text { certain types of fiscal adjustment, despite } \\
\text { union opposition, are not systematically } \\
\text { punished at the ballot box. }\end{array}$ \\
\hline $199^{8}$ & Alesina, A., Ardagna, S. & $\begin{array}{l}\text { The focus is to shed light on which features } \\
\text { of fiscal adjustments are more or less likely } \\
\text { to imply the fiscal tightening is expansionary } \\
\text { or contractionary. The paper examines the } \\
\text { evidence in OECD countries from the early } \\
\text { sixties. They conclude in summary that the } \\
\text { only solution is a sharp reduction in spending } \\
\text { to GDP ratios of several points of GDP. }\end{array}$ \\
\hline 2002 & Blanchard, O.J., Perotti, R. & $\begin{array}{l}\text { This paper characterizes the dynamic effects } \\
\text { of shocks in government spending and taxes } \\
\text { on U.S. activity in the postwar period. It does } \\
\text { so by using a mixed structural VAR/event } \\
\text { study approach. The results consistently } \\
\text { show positive government spending shocks } \\
\text { as having a positive effect on output, and } \\
\text { positive tax shocks as having a negative effect. }\end{array}$ \\
\hline 2005 & Christopher, S.A., and David, L.B. & $\begin{array}{l}\text { This paper examines the relationship } \\
\text { between fiscal deficits and growth for a panel } \\
\text { of } 45 \text { developing countries. The analysis } \\
\text { suggests that while the impacts on the } \\
\text { growth of taxes and grants are reasonably } \\
\text { straightforward, the implications of the } \\
\text { deficit is likely to be complex, depending on } \\
\text { the financing mix and the outstanding debt } \\
\text { stock. }\end{array}$ \\
\hline 2006 & Szalkolcai, G. & $\begin{array}{l}\text { The aim of this paper is to show that the } \\
\text { analysis of the twin deficit, the deficit of the } \\
\text { current account and the state budget must } \\
\text { be extended to the notion and analysis of the } \\
\text { triple deficit, the same two deficits and the } \\
\text { deficit of insufficiency of domestic savings. } \\
\text { The result is contradictory to the common } \\
\text { view that all problems are the consequences } \\
\text { of state overspending and all of them can be } \\
\text { solved by reducing the budget deficit and by } \\
\text { cutting state expenditures. }\end{array}$ \\
\hline
\end{tabular}




\begin{tabular}{|c|c|c|}
\hline YEAR & AUTHOR & RESULTS \\
\hline 2010 & Alesina and Ardagna & $\begin{array}{l}\text { They examined the evidence on episodes of } \\
\text { large stances in fiscal policy, both in cases of } \\
\text { fiscal stimuli and in that of fiscal adjustments } \\
\text { in OECD countries from } 1970-2007 \text {. They } \\
\text { confirm with the regression analysis that } \\
\text { also, adjustments on the spending side rather } \\
\text { than on than tax side are less likely to create } \\
\text { recessions. }\end{array}$ \\
\hline 2010 & Alfonso, A. & $\begin{array}{l}\text { Using alternative approaches to determine } \\
\text { fiscal episodes (EU-15, period 1970- } \\
2005 \text { ) they assess expansionary fiscal } \\
\text { consolidations in Europe, via panel models } \\
\text { for private consumption. They conclude } \\
\text { that there is some concurring evidence for } \\
\text { several budgetary spending items while the } \\
\text { asymmetric effects of fiscal episodes do not } \\
\text { seem to be corroborated by the results. }\end{array}$ \\
\hline 2010 & Romer and Romer & $\begin{array}{r}\text { The paper investigates the impact of tax } \\
\text { changes on economic activity. The behavior } \\
\text { of output following these more exogenous } \\
\text { changes indicates that tax increases are highly } \\
\text { contractionary. }\end{array}$ \\
\hline 2011 & Sever et.al. & $\begin{array}{l}\text { The objective of this paper is to analyze the } \\
\text { relationship between government budget } \\
\text { spending and the effect on the growth and } \\
\text { structure of the GDP of Croatia during } \\
\text { the past two decades. The main result } \\
\text { showed (VAR analysis) that the structure of } \\
\text { expenditures is essential for the effects of } \\
\text { budgetary spending on economic growth. } \\
\text { The reduction of capital expenditure reduces } \\
\text { the growth of the economy in the long and } \\
\text { short run. }\end{array}$ \\
\hline 2012 & Zezza, G. & $\begin{array}{l}\text { Paper presents a framework to assess the } \\
\text { impact of fiscal austerity in the Euro area, } \\
\text { as a response to the turmoil in the financial } \\
\text { markets. Their analysis suggests that fiscal } \\
\text { austerity in the presence of large public } \\
\text { deficit will have strong implications for } \\
\text { redistributing income from taxpayers to the } \\
\text { owners of such debt, who are likely to save a } \\
\text { larger share of their disposable income. }\end{array}$ \\
\hline 2012 & Auerbach and and Gorodnichenko & $\begin{array}{r}\text { A key issue in current research and policy } \\
\text { is the size of fiscal multipliers when the } \\
\text { economy is in recession. Using regime - } \\
\text { switching models, they find large differences } \\
\text { in the size of spending multipliers in } \\
\text { recessions and expansions with fiscal } \\
\text { policy being considerably more effective in } \\
\text { recessions than in expansions. }\end{array}$ \\
\hline
\end{tabular}




\begin{tabular}{|c|c|c|}
\hline YEAR & AUTHOR & RESULTS \\
\hline 2014 & Šimović et al. & $\begin{array}{l}\text { This paper analyzes the possibilities and } \\
\text { limitations of fiscal policy in Croatia. For } \\
\text { this purpose, they have been developed a } \\
\text { structural VAR model. Further fiscal policy } \\
\text { possibilities are synthesized through the } \\
\text { proposed measures of so-called "smart fiscal } \\
\text { consolidation." }\end{array}$ \\
\hline 2014 & Matsaganis and Leventi & $\begin{array}{l}\text { This paper (using a microsimulation model) } \\
\text { assesses the distributional implications of } \\
\text { the crisis in Greece, Spain, Italy and Portugal } \\
\text { from } 2009 \text { to } 2013 \text {. They find out that } \\
\text { austerity has affected the capacity of welfare } \\
\text { states to protect those affected. }\end{array}$ \\
\hline 2014 & Bilbao-Ubillos, J., Fernandez-Sainz, A.I. & $\begin{array}{l}\text { The article seeks to compare the significance } \\
\text { of the links between fiscal policies and } \\
\text { economic growth in the Eurozone before } \\
\text { and after the imposition of adjustments. The } \\
\text { results of regression could serve to accept } \\
\text { the hypothesis that the impact of austerity } \\
\text { policies has shrunk economic activity more } \\
\text { than expected. }\end{array}$ \\
\hline 2014 & Radulescu, M. Druica, E. & $\begin{array}{l}\text { Using linear regression, this article presents } \\
\text { the impact of the fiscal and monetary policies } \\
\text { on attracting the foreign direct investments } \\
\text { (FDIs) in Romania, based on monthly data } \\
\text { series during } 2000-2010 \text {. Fiscal factors } \\
\text { (mainly direct taxes) seem to play a less } \\
\text { important role, being relevant only in the } \\
\text { long-term. Only by improving the other } \\
\text { non-financial factors fiscal stimulus can be } \\
\text { effective in attracting FDIs and supporting } \\
\text { the economic growth at the same time. }\end{array}$ \\
\hline 2014 & Shakina, E., Barajas, A. & $\begin{array}{r}\text { This study investigates factors of corporate } \\
\text { success over the crisis period } 2008-2009 \text {. } \\
\text { Regression analysis showed that investment } \\
\text { restriction is not the best response to an } \\
\text { economic recession. }\end{array}$ \\
\hline 2014 & Caporale, G.M., Škare, M. & $\begin{array}{r}\text { The paper analyses the linkages between } \\
\text { output growth, inflation and employment } \\
\text { growth for } 119 \text { countries over the period } \\
1970-2008 \text { using a panel VAR approach. It } \\
\text { shows the existence of statistically significant } \\
\text { relationships as well as heterogeneity across } \\
\text { countries and panels. }\end{array}$ \\
\hline
\end{tabular}

Source: Author 


\section{DATAANALYSIS}

This chapter presents a framework to assess the analysis of austerity policy for $10 \mathrm{EU}$ countries ${ }^{1}$ in the period after a global financial crisis.

Namely, because of the problem of high public debt (especially countries which have exceeded the threshold value of 60 percent of GDP) and contraction in GDP growth rate, most governments are at the crossroad between a policy of fiscal stimulus (that should promote employment) or fiscal adjustment.

While most of the developed countries have been using first options, the weaker member states to reduce high debt promote the sharp cuts policy- fiscal austerity. However, the problem is that the same weak national economies which should promote politics of austerity have still a problem with the deficit reduction and high public debt and at the same time major problem with unemployment, poverty, and inequality.

Table 3.: Government finance statistics

\begin{tabular}{|c|c|c|c|c|c|c|c|}
\hline Countries & Indicators & 2009 & 2010 & 2011 & 2012 & 2013 & 2014 \\
\hline \multirow[t]{5}{*}{ Portugal } & $\begin{array}{r}\text { Real GDP growth rate- } \\
\text { volume }\end{array}$ & -3 & 1,9 & $-1,8$ & $-3,3$ & $-1,4$ & 0,9 \\
\hline & $\begin{array}{r}\text { Total general } \\
\text { government revenue } \\
(\% \text { of GDP })\end{array}$ & 40,4 & 40,6 & 42,6 & 43 & 45,2 & / \\
\hline & $\begin{array}{r}\text { Total general } \\
\text { government } \\
\text { expenditure (\% of } \\
\text { GDP) }\end{array}$ & $5^{0,2}$ & $5^{1,8}$ & $5^{\circ}, 0$ & 48,5 & $5^{0,1}$ & / \\
\hline & $\begin{array}{r}\text { Government deficit } \\
\text { (net lending }(+) / \text { net } \\
\text { borrowing }(-)(\% \text { of } \\
\text { GDP) }\end{array}$ & $-9,8$ & $-11,2$ & $-7,4$ & $-5,5$ & $-4,9$ & / \\
\hline & $\begin{array}{l}\text { General government } \\
\text { gross debt ( } \% \text { of GDP) }\end{array}$ & 83,6 & 96,2 & 111,1 & 124,8 & 128 & I \\
\hline \multirow[t]{4}{*}{ Italy } & $\begin{array}{r}\text { Real GDP growth rate- } \\
\text { volume }\end{array}$ & $-5,5$ & 1,7 & 0,6 & $-2,8$ & $-1,7$ & $-0,4$ \\
\hline & $\begin{array}{r}\text { Total general } \\
\text { government revenue } \\
(\% \text { of GDP })\end{array}$ & 45,9 & 45,6 & 45,6 & 47,4 & 47,7 & I \\
\hline & $\begin{array}{r}\text { Total general } \\
\text { government } \\
\text { expenditure }(\% \text { of } \\
\text { GDP) }\end{array}$ & $5^{1,1}$ & 49,9 & 49,1 & $5^{\circ}, 4$ & $5^{0,5}$ & I \\
\hline & $\begin{array}{r}\text { Government deficit } \\
\text { (net lending }(+) / \text { net } \\
\text { borrowing }(-)(\% \text { of } \\
\text { GDP) }\end{array}$ & $-5,2$ & $-4,3$ & $-3,5$ & -3 & $-2,8$ & / \\
\hline
\end{tabular}

1 The countries included in the paper are the following: Portugal, Italy, Greece, Spain, Latvia, Lithuania, UK, Croatia, Estonia, Germany. 


\begin{tabular}{|c|c|c|c|c|c|c|c|}
\hline Countries & Indicators & 2009 & 2010 & 2011 & 2012 & 2013 & 2014 \\
\hline \multirow{6}{*}{ Greece } & $\begin{array}{l}\text { General government } \\
\text { gross debt ( } \% \text { of GDP) }\end{array}$ & 112,5 & 115,3 & 116,4 & 122,2 & 127,9 & I \\
\hline & $\begin{array}{r}\text { Real GDP growth rate- } \\
\text { volume }\end{array}$ & $-4,4$ & $-5,4$ & $-8,9$ & $-6,6$ & $-3,9$ & 0,8 \\
\hline & $\begin{array}{r}\text { Total general } \\
\text { government revenue } \\
(\% \text { of GDP })\end{array}$ & 38,7 & 41 & $4^{43,6}$ & 45,2 & 47 & / \\
\hline & $\begin{array}{r}\text { Total general } \\
\text { government } \\
\text { expenditure (\% of } \\
\text { GDP) }\end{array}$ & 54,0 & $5^{2,1}$ & $5^{3,7}$ & $5^{3,8}$ & 59,2 & / \\
\hline & $\begin{array}{r}\text { Government deficit } \\
\text { (net lending }(+) / \text { net } \\
\text { borrowing }(-)(\% \text { of } \\
\text { GDP })\end{array}$ & $-15,3$ & $-11,1$ & $-10,1$ & $-8,6$ & $-12,2$ & I \\
\hline & $\begin{array}{l}\text { General government } \\
\text { gross debt ( } \% \text { of GDP) }\end{array}$ & 126,8 & 146 & $177^{1,3}$ & 156,9 & 174,9 & / \\
\hline \multirow[t]{5}{*}{ Spain } & $\begin{array}{r}\text { Real GDP growth rate- } \\
\text { volume }\end{array}$ & $-3,6$ & ○ & $-0,6$ & $-2,1$ & $-1,2$ & 1,4 \\
\hline & $\begin{array}{r}\text { Total general } \\
\text { government revenue } \\
(\% \text { of GDP) }\end{array}$ & 34,8 & 36,2 & 36 & 37 & 37,5 & / \\
\hline & $\begin{array}{r}\text { Total general } \\
\text { government } \\
\text { expenditure (\% of } \\
\text { GDP) }\end{array}$ & 45,8 & 45,6 & 45,4 & 47,3 & 44,3 & / \\
\hline & $\begin{array}{r}\text { Government deficit } \\
\text { (net lending }(+) / \text { net } \\
\text { borrowing }(-)(\% \text { of } \\
\text { GDP })\end{array}$ & -11 & $-9,4$ & $-9,4$ & $-10,3$ & $-6,8$ & / \\
\hline & $\begin{array}{l}\text { General government } \\
\text { gross debt ( } \% \text { of GDP) }\end{array}$ & 52,7 & 60,1 & 69,2 & 84,4 & 92,1 & / \\
\hline \multirow[t]{5}{*}{ Latvia } & $\begin{array}{r}\text { Real GDP growth rate- } \\
\text { volume }\end{array}$ & $-14,2$ & $-2,9$ & 5 & 4,8 & 4,2 & 2,4 \\
\hline & $\begin{array}{r}\text { Total general } \\
\text { government revenue } \\
(\% \text { of GDP })\end{array}$ & 34,5 & 36 & 35,5 & 35,8 & 34,8 & / \\
\hline & $\begin{array}{r}\text { Total general } \\
\text { government } \\
\text { expenditure (\% of } \\
\text { GDP) }\end{array}$ & $4^{3,4}$ & 44,2 & 38,9 & 36,6 & 35,7 & / \\
\hline & $\begin{array}{r}\text { Government deficit } \\
\text { (net lending }(+) / \text { net } \\
\text { borrowing }(-)(\% \text { of } \\
\text { GDP) }\end{array}$ & $-8,9$ & $-8,2$ & $-3,4$ & $-0,8$ & $-0,9$ & / \\
\hline & $\begin{array}{r}\text { General government } \\
\text { gross debt ( } \% \text { of GDP) }\end{array}$ & 36,4 & 46,8 & 42,7 & 40,9 & 38,2 & / \\
\hline Lithuania & $\begin{array}{r}\text { Real GDP growth rate- } \\
\text { volume }\end{array}$ & $-14,8$ & 1,6 & 6,1 & 3,8 & 3,3 & 2,9 \\
\hline
\end{tabular}




\begin{tabular}{|c|c|c|c|c|c|c|c|}
\hline Countries & Indicators & 2009 & 2010 & 2011 & 2012 & 2013 & 2014 \\
\hline \multirow{9}{*}{ UK } & $\begin{array}{r}\text { Total general } \\
\text { government revenue } \\
(\% \text { of GDP) }\end{array}$ & 35,6 & 35,4 & 33,5 & 33 & 32,8 & / \\
\hline & $\begin{array}{r}\text { Total general } \\
\text { government } \\
\text { expenditure (\% of } \\
\text { GDP) }\end{array}$ & 44,9 & 42,3 & 42,5 & 36,1 & 35,5 & / \\
\hline & $\begin{array}{r}\text { Government deficit } \\
\text { (net lending }(+) / \text { net } \\
\text { borrowing }(-)(\% \text { of } \\
\text { GDP) }\end{array}$ & $-9,3$ & $-6,9$ & -9 & $-3,1$ & $-2,7$ & / \\
\hline & $\begin{array}{l}\text { General government } \\
\text { gross debt (\% of GDP) }\end{array}$ & 29 & 36,3 & 37,3 & 39,9 & 39 & / \\
\hline & $\begin{array}{r}\text { Real GDP growth rate- } \\
\text { volume }\end{array}$ & $-4,3$ & 1,9 & 1,6 & 0,7 & 1,7 & 2,6 \\
\hline & $\begin{array}{r}\text { Total general } \\
\text { government revenue } \\
(\% \text { of GDP) }\end{array}$ & 38,9 & 39 & 39,2 & 38,7 & 39,7 & / \\
\hline & $\begin{array}{r}\text { Total general } \\
\text { government } \\
\text { expenditure (\% of } \\
\text { GDP) }\end{array}$ & 49,7 & 48,6 & 46,8 & 47,0 & 45,5 & I \\
\hline & $\begin{array}{r}\text { Government deficit } \\
\text { (net lending }(+) / \text { net } \\
\text { borrowing }(-)(\% \text { of } \\
\text { GDP })\end{array}$ & $-10,8$ & $-9,6$ & $-7,6$ & $-8,3$ & $-5,8$ & / \\
\hline & $\begin{array}{l}\text { General government } \\
\text { gross debt ( } \% \text { of GDP) }\end{array}$ & 65,9 & $7^{6,4}$ & 81,9 & 85,8 & 87,2 & I \\
\hline \multirow[t]{5}{*}{ Croatia } & $\begin{array}{r}\text { Real GDP growth rate- } \\
\text { volume }\end{array}$ & $-7,4$ & $-1,7$ & $-0,3$ & $-2,2$ & $-0,9$ & $-0,4$ \\
\hline & $\begin{array}{r}\text { Total general } \\
\text { government revenue } \\
(\% \text { of GDP) }\end{array}$ & 41,2 & $4,0,8$ & $4,0,6$ & 41,3 & 41,8 & I \\
\hline & $\begin{array}{r}\text { Total general } \\
\text { government } \\
\text { expenditure (\% of } \\
\text { GDP) }\end{array}$ & 47,2 & $4,6,8$ & 48,2 & 46,9 & 47,0 & I \\
\hline & $\begin{array}{r}\text { Government deficit } \\
\text { (net lending }(+) / \text { net } \\
\text { borrowing }(-)(\% \text { of } \\
\text { GDP })\end{array}$ & -6 & -6 & $-7,6$ & $-5,6$ & $-5,2$ & I \\
\hline & $\begin{array}{l}\text { General government } \\
\text { gross debt (\% of GDP) }\end{array}$ & 44,5 & $5^{2,8}$ & 59,9 & 64,4 & 75,7 & / \\
\hline \multirow[t]{3}{*}{ Estonia } & $\begin{array}{r}\text { Real GDP growth rate- } \\
\text { volume }\end{array}$ & $-14,7$ & 2,5 & 8,3 & 4,7 & 1,6 & 2,1 \\
\hline & $\begin{array}{r}\text { Total general } \\
\text { government revenue } \\
(\% \text { of GDP })\end{array}$ & 1 & $4,0,6$ & 39,1 & 39,5 & 38,4 & I \\
\hline & $\begin{array}{r}\text { Total general } \\
\text { government } \\
\text { expenditure (\% of } \\
\text { GDP) }\end{array}$ & I & 40.4 & 38,0 & 39,7 & 38,9 & I \\
\hline
\end{tabular}




\begin{tabular}{|c|c|c|c|c|c|c|c|}
\hline Countries & Indicators & 2009 & 2010 & 2011 & 2012 & 2013 & 2014 \\
\hline \multirow{7}{*}{ Germany } & $\begin{array}{r}\text { Government deficit } \\
\text { (net lending }(+) / \text { net } \\
\text { borrowing }(-)(\% \text { of } \\
\text { GDP })\end{array}$ & / & 0,2 & 1,1 & $-0,2$ & $-0,5$ & I \\
\hline & $\begin{array}{l}\text { General government } \\
\text { gross debt }(\% \text { of GDP) }\end{array}$ & I & 6,5 & 6 & 9,7 & 10,1 & / \\
\hline & $\begin{array}{r}\text { Real GDP growth rate- } \\
\text { volume }\end{array}$ & $-5,6$ & 4,1 & 3,6 & 0,4 & 0,1 & 1,6 \\
\hline & $\begin{array}{r}\text { Total general } \\
\text { government revenue } \\
\text { ( } \% \text { of GDP) }\end{array}$ & 44,4 & $4^{3,1}$ & $4^{3,7}$ & 44,3 & 44,5 & / \\
\hline & $\begin{array}{r}\text { Total general } \\
\text { government } \\
\text { expenditure (\% of } \\
\text { GDP) }\end{array}$ & 47,4 & 47,9 & 45,2 & 44,7 & 44,3 & I \\
\hline & $\begin{array}{r}\text { Government deficit } \\
\text { (net lending }(+) / \text { net } \\
\text { borrowing }(-)(\% \text { of } \\
\text { GDP })\end{array}$ & -3 & $-4,8$ & $-1,5$ & $-0,4$ & 0,2 & I \\
\hline & $\begin{array}{l}\text { General government } \\
\text { gross debt (\% of GDP) }\end{array}$ & 72,4 & 80,3 & 77,6 & 79 & $7^{6,9}$ & I \\
\hline
\end{tabular}

Source: Autors`systematization according to:Eurostat Real GDP growth rate:

http://ec.europa.eu/eurostat/tgm/table.do?tab=table\&init=1\&language=en\&pcode=tecoo $115 \&$ plugin=1 Total general government revenue:

http://ec.europa.eu/eurostat/tgm/table.do? tab=table\&init=1\&language =en\&pcode=teco0o21 \&plugin=1 Total general government expenditure: http://appsso.eurostat.ec.europa.eu/nui/show.do?dataset=gov_10a main\&lang=en

General government gross debt:

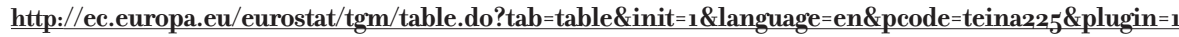

From the Table 3 . we can see that in 2013 countries exceeding the threshold value of 60 percent of GDP of general government gross debt (\% of GDP) were: Portugal $128 \%$, Italy $127,9 \%$, Greece $174,9 \%$, Spain $92,1 \%$, Croatia $75,7 \%$, UK $87,2 \%$, and Germany $76,9 \%$. In contrast, there are countries like Latvia reaching $38,2 \%$, Lithuania $39 \%$, Estonia $10,1 \%$. Further, GDP growth rate in 2013 in Portugal was $-1,4$, in Italy -1,7, Greece -3,9, Spain -1,2, Croatia -0,9, in contrast with Latvia 4,2, Lithuania 3,3, UK 1, 7 , Estonia 1,6, Germany o,1.

To achieve a balanced budget and reduce debts, governments have implemented a policy of austerity neglecting the diversity of sectoral structures. The weak and negative growth rates point to the fundamental problem - the structure of the Eurozone. Due to different economy structure, countries have followed different paths to austerity.

Whole adjustment program has been bad for weaker countries, which already facing with the downturn in the economy. Finally, the impact of austerity has been exacerbated and did not solve the problem with the deficit. 
For example, in 2013 Portugal reached deficit of $-4,9 \%$, Greece $-12,2 \%$, Spain $-6,8$, Croatia $-5,2 \%$. It is worth noticing that countries like the UK also had a high deficit, but also positive GDP growth rate (because of the different structure of deficit and deficit financing).

It is critical to highlight that the magnitude of payment depends on how the deficit is financed and under what conditions (interest rates, repayment period, borrowing abroad or domestically) and for what it is used.

Also, negative growth rates in GDP growth during the period 2009-2014, was also associated with the structure of demand which negatively contributed to growth (see table 4 ).

Table 4.: World Development Indicators: Structure of demand

\begin{tabular}{|c|c|c|c|c|c|c|c|}
\hline Countries & Indicators & 2009 & 2010 & 2011 & 2012 & 2013 & 2014 \\
\hline \multirow[t]{5}{*}{ Portugal } & $\begin{array}{r}\text { Final consumption } \\
\text { expenditure of } \\
\text { households and non- } \\
\text { profit institutions } \\
\text { serving }\end{array}$ & 64,7 & 65,8 & 65,8 & 65,7 & 64,7 & 65,2 \\
\hline & $\begin{array}{r}\text { Final consumption } \\
\text { expenditure of general } \\
\text { government }\end{array}$ & 21,4 & 20,7 & 19,9 & 18,3 & 19 & 18,4 \\
\hline & $\begin{array}{r}\text { Gross fixed capital } \\
\text { formation (investment) }\end{array}$ & 21,1 & 20,5 & 18,4 & 16,3 & 15,1 & 15 \\
\hline & $\begin{array}{r}\text { Imports of goods and } \\
\text { services ( } \% \text { GDP) }\end{array}$ & 34,0 & 37,4 & 38,6 & 38,0 & 38,3 & / \\
\hline & $\begin{array}{l}\text { Exports of goods and } \\
\text { services ( } \% \text { of GDP) }\end{array}$ & 27,1 & 29,9 & 34,3 & 37,3 & 39,3 & / \\
\hline \multirow[t]{5}{*}{ Italy } & $\begin{array}{r}\text { Final consumption } \\
\text { expenditure of } \\
\text { households and non- } \\
\text { profit institutions } \\
\text { serving }\end{array}$ & 60,7 & 61 & 61,5 & 61,6 & 60,8 & $6 \circ, 8$ \\
\hline & $\begin{array}{r}\text { Final consumption } \\
\text { expenditure of general } \\
\text { government }\end{array}$ & 20,6 & 20,4 & 19,6 & 19,6 & 19,6 & 19,5 \\
\hline & $\begin{array}{r}\text { Gross fixed capital } \\
\text { formation (investment) }\end{array}$ & 20 & 19,9 & 19,6 & 18,3 & 17,4 & 16,8 \\
\hline & $\begin{array}{l}\text { Imports of goods and } \\
\text { services (\% GDP) }\end{array}$ & 23,1 & 27,1 & 28,6 & 27,4 & 26,3 & I \\
\hline & $\begin{array}{l}\text { Exports of goods and } \\
\text { services ( } \% \text { of GDP) }\end{array}$ & 22,5 & 25,2 & 27 & 28,3 & 28,6 & I \\
\hline \multirow[t]{2}{*}{ Greece } & $\begin{array}{r}\text { Final consumption } \\
\text { expenditure of } \\
\text { households and non- } \\
\text { profit institutions } \\
\text { serving }\end{array}$ & 69,3 & 70 & 69,8 & 69,4 & $7^{1,2}$ & 72 \\
\hline & $\begin{array}{r}\text { Final consumption } \\
\text { expenditure of general } \\
\text { government }\end{array}$ & 22,7 & 21,6 & 21,2 & 21,2 & 20 & 19,8 \\
\hline
\end{tabular}




\begin{tabular}{|c|c|c|c|c|c|c|c|}
\hline Countries & Indicators & 2009 & 2010 & 2011 & 2012 & 2013 & 2014 \\
\hline \multirow{8}{*}{ Spain } & $\begin{array}{r}\text { Gross fixed capital } \\
\text { formation (investment) }\end{array}$ & 20,9 & 17,3 & 15,4 & 11,7 & 11.2 & 11,6 \\
\hline & $\begin{array}{r}\text { Imports of goods and } \\
\text { services (\% GDP) }\end{array}$ & 29,4 & 30,7 & 32,3 & 32,7 & 33,2 & / \\
\hline & $\begin{array}{l}\text { Exports of goods and } \\
\text { services (\% of GDP) }\end{array}$ & 19 & 22,1 & 25,5 & 28,8 & $3 \circ, 3$ & / \\
\hline & $\begin{array}{r}\text { Final consumption } \\
\text { expenditure of } \\
\text { households and non- } \\
\text { profit institutions } \\
\text { serving }\end{array}$ & $5^{6,1}$ & 57,2 & 57,9 & $5^{8,6}$ & $5^{8,2}$ & 59 \\
\hline & $\begin{array}{r}\text { Final consumption } \\
\text { expenditure of general } \\
\text { government }\end{array}$ & 20,5 & 20,5 & 20,4 & 19,6 & 19,5 & 19,2 \\
\hline & $\begin{array}{r}\text { Gross fixed capital } \\
\text { formation (investment) }\end{array}$ & 24,3 & 23 & 21,4 & 19,7 & 18,5 & 18,9 \\
\hline & $\begin{array}{r}\text { Imports of goods and } \\
\text { services (\% GDP) }\end{array}$ & 23,8 & 26,8 & 29 & 28,8 & 28,1 & / \\
\hline & $\begin{array}{l}\text { Exports of goods and } \\
\text { services ( } \% \text { of GDP) }\end{array}$ & 22,7 & 25,5 & 28,8 & $3 \circ, 3$ & 31,6 & / \\
\hline \multirow[t]{5}{*}{ Latvia } & $\begin{array}{r}\text { Final consumption } \\
\text { expenditure of } \\
\text { households and non- } \\
\text { profit institutions } \\
\text { serving }\end{array}$ & 61,3 & 63,9 & 62,5 & 61,2 & 61,9 & 61,5 \\
\hline & $\begin{array}{r}\text { Final consumption } \\
\text { expenditure of general } \\
\text { government }\end{array}$ & 18,9 & 18,1 & 18,2 & 17,2 & 17,6 & 17,6 \\
\hline & $\begin{array}{r}\text { Gross fixed capital } \\
\text { formation (investment) }\end{array}$ & 22,5 & 19,1 & 22,1 & 25,2 & 23,3 & 23,2 \\
\hline & $\begin{array}{r}\text { Imports of goods and } \\
\text { services (\% GDP) }\end{array}$ & 45,4 & 55,2 & 62,7 & / & / & / \\
\hline & $\begin{array}{l}\text { Exports of goods and } \\
\text { services ( } \% \text { of GDP) }\end{array}$ & $4^{3,9}$ & $5^{3,8}$ & $5^{8,8}$ & / & / & / \\
\hline \multirow[t]{5}{*}{ Lithuania } & $\begin{array}{r}\text { Final consumption } \\
\text { expenditure of } \\
\text { households and non- } \\
\text { profit institutions } \\
\text { serving }\end{array}$ & 68,1 & 64,1 & 62,5 & 62,6 & 62,8 & 63,9 \\
\hline & $\begin{array}{r}\text { Final consumption } \\
\text { expenditure of general } \\
\text { government }\end{array}$ & 21 & 19,7 & 18,2 & 17,3 & 16,8 & 17,1 \\
\hline & $\begin{array}{r}\text { Gross fixed capital } \\
\text { formation (investment) }\end{array}$ & 17,9 & 16,9 & 18,4 & 17,3 & 18,2 & 19,2 \\
\hline & $\begin{array}{r}\text { Imports of goods and } \\
\text { services (\% GDP) }\end{array}$ & 55,7 & 68,8 & $7^{8,6}$ & I & / & I \\
\hline & $\begin{array}{l}\text { Exports of goods and } \\
\text { services ( } \% \text { of GDP) }\end{array}$ & 54,3 & 67,8 & 77,1 & / & / & / \\
\hline
\end{tabular}




\begin{tabular}{|c|c|c|c|c|c|c|c|}
\hline Countries & Indicators & 2009 & 2010 & 2011 & 2012 & 2013 & 2014 \\
\hline \multirow[t]{5}{*}{ UK } & $\begin{array}{r}\text { Final consumption } \\
\text { expenditure of } \\
\text { households and non- } \\
\text { profit institutions } \\
\text { serving }\end{array}$ & 64,7 & 64,4 & 64,2 & 64,8 & 64,9 & 64,4 \\
\hline & $\begin{array}{r}\text { Final consumption } \\
\text { expenditure of general } \\
\text { government }\end{array}$ & 22,3 & 21,6 & 20,9 & 20,8 & 20,1 & 19,7 \\
\hline & $\begin{array}{l}\text { Gross fixed capital } \\
\text { formation (investment) }\end{array}$ & 16,1 & 16,1 & 16,1 & 16,2 & 16,5 & 17 \\
\hline & $\begin{array}{l}\text { Imports of goods and } \\
\text { services (\% GDP) }\end{array}$ & 28,9 & 31,1 & 32,3 & 32,3 & 31,7 & I \\
\hline & $\begin{array}{l}\text { Exports of goods and } \\
\text { services (\% of GDP) }\end{array}$ & 27 & 28,7 & $3 \circ, 9$ & 30,2 & 29,8 & I \\
\hline \multirow[t]{5}{*}{ Croatia } & $\begin{array}{r}\text { Final consumption } \\
\text { expenditure of } \\
\text { households and non- } \\
\text { profit institutions } \\
\text { serving }\end{array}$ & $5^{8,4}$ & $5^{8,9}$ & 59,7 & 60,2 & 60,6 & 60,2 \\
\hline & $\begin{array}{r}\text { Final consumption } \\
\text { expenditure of general } \\
\text { government }\end{array}$ & 20,3 & 20,1 & 20,1 & 20,1 & 20 & 19,8 \\
\hline & $\begin{array}{l}\text { Gross fixed capital } \\
\text { formation (investment) }\end{array}$ & 25,2 & 21,3 & 20,3 & 19,6 & 19,3 & 18,6 \\
\hline & $\begin{array}{r}\text { Imports of goods and } \\
\text { services ( } \% \text { GDP) }\end{array}$ & 38,2 & 38,2 & 40,9 & 41,1 & 42,5 & I \\
\hline & $\begin{array}{l}\text { Exports of goods and } \\
\text { services (\% of GDP) }\end{array}$ & 34,5 & 37,7 & 4.0 .4 & 41,6 & 42,9 & I \\
\hline \multirow[t]{5}{*}{ Estonia } & $\begin{array}{r}\text { Final consumption } \\
\text { expenditure of } \\
\text { households and non- } \\
\text { profit institutions } \\
\text { serving }\end{array}$ & $5^{3,4}$ & $5^{2,3}$ & $5^{\circ}, 5$ & $5^{1,1}$ & $5^{1,5}$ & $5^{2,1}$ \\
\hline & $\begin{array}{r}\text { Final consumption } \\
\text { expenditure of general } \\
\text { government }\end{array}$ & 21 & 20,1 & 18,9 & 18,7 & 19,1 & 19,6 \\
\hline & $\begin{array}{l}\text { Gross fixed capital } \\
\text { formation (investment) }\end{array}$ & 22,7 & 21,2 & 25,7 & 27 & 27,3 & 25,8 \\
\hline & $\begin{array}{r}\text { Imports of goods and } \\
\text { services ( } \% \text { GDP) }\end{array}$ & 55,9 & 68,8 & 82,5 & 88,2 & 85,2 & I \\
\hline & $\begin{array}{l}\text { Exports of goods and } \\
\text { services (\% of GDP) }\end{array}$ & 60,8 & 75,1 & 86,1 & 88,3 & 86,1 & \\
\hline \multirow[t]{2}{*}{ Germany } & $\begin{array}{r}\text { Final consumption } \\
\text { expenditure of } \\
\text { households and non- } \\
\text { profit institutions } \\
\text { serving households }\end{array}$ & 57,3 & $5^{6,1}$ & 55,8 & $5^{6}$ & 55,9 & 55,3 \\
\hline & $\begin{array}{r}\text { Final consumption } \\
\text { expenditure of general } \\
\text { government }\end{array}$ & 19,6 & 19,2 & 18,7 & 19 & 19,3 & 19,3 \\
\hline
\end{tabular}




\begin{tabular}{|r|c|r|r|r|r|r|r|}
\hline Countries & Indicators & $\mathbf{2 0 0 9}$ & $\mathbf{2 0 1 0}$ & $\mathbf{2 0 1 1}$ & $\mathbf{2 0 1 2}$ & $\mathbf{2 0 1 3}$ & $\mathbf{2 0 1 4}$ \\
\hline \multirow{7}{*}{$\begin{array}{r}\text { Gross fixed capital } \\
\text { formation (investment) }\end{array}$} & 19,1 & 19,3 & 20,2 & 20 & 19,8 & 20 \\
$\begin{array}{r}\text { Imports of goods and } \\
\text { services (\% GDP) }\end{array}$ & 32,9 & 37,1 & 4,0 & 40 & 39,8 & $/$ \\
& $\begin{array}{r}\text { Exports of goods and } \\
\text { services (\% of GDP) }\end{array}$ & 37,8 & 42,3 & 44,8 & 45,9 & 45,6 & $/$ \\
\hline
\end{tabular}

Source: Final consumption expenditure of households and non-profit institutions serving households: Eurostat: http://ec.europa.eu/eurostat/tgm/printTable.do? tab=table\&plugin=1\&language=en\&pcode=te coooog\&printPreview =true

Final consumption expenditure of general government:

http://ec.europa.eu/eurostat/tgm/printTable.do?tab=table\&plugin= $1 \&$ language $=$ en $\&$ pcode $=$ tecooo10\& printPreview=true

Gross fixed capital formation (investment):

http://ec.europa.eu/eurostat/tgm/printTable.do?tab=table\&plugin=1\&language $=$ en\&pcode $=$ tecooo $11 \&$ printPreview=true

Imports of goods and services (\% GDP): The World Bank:

http://data.worldbank.org/indicator/NE.IMP.GNFS.ZS

Exports of goods and services (\% of GDP):

http://data.worldbank.org/indicator/NE.EXP.GNFS.ZS/countries

From the Table 4, it can be seen that structure of demand has a large contribution to economic growth. Also in countries like Estonia, UK, Latvia, Lithuania, Germany the rise in GDP growth, or the positive GDP growth during the period 20092014 was associated with a sharp surge in investment. Gross fixed capital formation in the period of 2009-2013 for Estonia was (22,7-27,3), UK(16,1-17), Latvia (22,523,3), Lithuania (17,9-18,2), Germany (19,1-19,8).

In contrary countries like Portugal, Italy, Greece, Spain, Croatia, in the period of 2009-2013) had a negative GDP growth rate and decreasing trend in investments.

In the period of 2009-2013 Gross fixed capital formation (investment) in Portugal was (21,1-15,1), in Italy (20-17,4), Greece (20,9-11,6), Spain (24,3-18,9), Croatia (25,2-19,3).

It can be concluded that the reduction of capital expenditure especially during the recession it is not a solution for sustainable growth.

In the structure of aggregate demand in 2013, all countries except Estonia (the highest share in aggregate demand was the export of goods and services with 86,1\%) recorded the highest share in final consumption expenditure of households and non-profit institutions serving. In 2013, the largest proportion in final consumption expenditure of households and non-profit institutions had Greece $7_{1}^{1,2} \%$, UK with $64,9 \%$, Portugal $64,7 \%$, in Italy 60,8\%, Spain $58,2 \%$, Latvia $61,9 \%$, Lithuania $62,8 \%$, Croatia $60,6 \%$, Estonia $51,5 \%$, Germany $55,9 \%$.

Further, in the same period 2009-2013 because of politics of austerity, final consumption expenditure of general government decreased in all countries, while final consumption expenditure of households and nonprofit institutions just in few countries like; Lithuania, Estonia, Germany. 
Shortly, the share of final consumption expenditure in general government decreased, and it can be seen dramatically decline in investment, due to it is very interesting that export it has not been decreased.

In the period 2009-2013 export has increased in Portugal (27,1-39,3\%), Italy $\left(22,5^{-28,6 \%}\right)$, Greece $(19-30,3 \%)$, Spain $\left(22,7^{-31}, 6 \%\right)$, Latvia $(4,3,9-58,8 \%$ in 2011), Lithuania $(54,3-77,1 \%$ in 2011), UK $(27-29,8 \%)$, Croatia $(34,5-4,2,9 \%)$, Estonia $(6 \circ, 8-86,1 \%)$, Germany $(37,8-45,6 \%)$.

It can be concluded that mechanism which links the balance of payment and government budget indicates a lack of tax revenue of public sector, which is offset mostly by borrowing abroad. Namely, the problem with the current deficit cannot be solved only by cutting the state expenditures and especially capital investment.

The following Table 5 . indicates the most fundamental elements of the austerity open issues. It analyzes the social impact of fiscal austerity; unemployment, youth unemployment and poverty.

Table 5.: Basic socio-economic indicators for 2009-2013

\begin{tabular}{|c|c|c|c|c|c|c|}
\hline Countries & Indicators & 2009 & 2010 & 2011 & 2012 & 2013 \\
\hline \multirow[t]{3}{*}{ Portugal } & Unemployment rate ( $\%$ of GDP) & 9,1 & 11,8 & 13,4 & 15,8 & 17,7 \\
\hline & $\begin{array}{r}\text { Unemployment, youth, total (\% } \\
\text { of total labor force ages 15-24) } \\
\text { national estimate(WDI-2) }\end{array}$ & 20 & 22,2 & $3 \circ$ & 37,5 & 37,9 \\
\hline & $\begin{array}{l}\text { At risk of poverty rate by poverty } \\
\text { threshold age and sex }\end{array}$ & 17,9 & 17,9 & 18 & 17,9 & 18,7 \\
\hline \multirow[t]{3}{*}{ Italy } & Unemployment rate ( $\%$ of GDP) & 7,8 & 8,4 & 8,4 & 10,7 & 12,2 \\
\hline & $\begin{array}{r}\text { Unemployment, youth, total ( } \% \\
\text { of total labor force ages 15-24) } \\
\text { national estimate(WDI-2) }\end{array}$ & 25,5 & 27,7 & 29,1 & 35,2 & 39,7 \\
\hline & $\begin{array}{l}\text { At risk of poverty rate by poverty } \\
\text { threshold age and sex }\end{array}$ & 18,4 & 18,2 & 19,6 & 19,4 & 19,1 \\
\hline \multirow[t]{3}{*}{ Greece } & Unemployment rate ( $\%$ of GDP) & 9,5 & 12,5 & 17,7 & 24,2 & 27,3 \\
\hline & $\begin{array}{r}\text { Unemployment, youth, total (\% } \\
\text { of total labor force ages } 15-24) \\
\text { national estimate(WDI-2) }\end{array}$ & 25,5 & 32,4 & 44,0 & 54,7 & $5^{8,4}$ \\
\hline & $\begin{array}{r}\text { At risk of poverty rate by poverty } \\
\text { threshold age and sex }\end{array}$ & 19,7 & 20,1 & 21,4 & 23,1 & 23,1 \\
\hline \multirow[t]{3}{*}{ Spain } & Unemployment rate ( $\%$ of GDP) & 18,1 & 20,2 & 21,7 & 25,2 & 26,6 \\
\hline & $\begin{array}{r}\text { Unemployment, youth, total (\% } \\
\text { of total labor force ages } 15-24) \\
\text { national estimate(WDI-2) }\end{array}$ & 38,5 & 42,5 & 47,0 & 54,2 & 57,2 \\
\hline & $\begin{array}{l}\text { At risk of poverty rate by poverty } \\
\text { threshold age and sex }\end{array}$ & 20,4 & 20,7 & 20,6 & 20,8 & 20,4 \\
\hline \multirow[t]{2}{*}{ Latvia } & Unemployment rate ( $\%$ of GDP) & 17,1 & 18,7 & 16,2 & 14,9 & 11,1 \\
\hline & $\begin{array}{r}\text { Unemployment, youth, total (\% } \\
\left.\text { of total labor force ages } 15^{-24}\right) \\
\text { national estimate(WDI-2) }\end{array}$ & 33,9 & 34,9 & 31 & 28,2 & 20,2 \\
\hline
\end{tabular}




\begin{tabular}{|c|c|c|c|c|c|c|}
\hline Countries & Indicators & 2009 & 2010 & 2011 & 2012 & 2013 \\
\hline \multirow{4}{*}{ Lithuania } & $\begin{array}{r}\text { At risk of poverty rate by poverty } \\
\text { threshold age and sex }\end{array}$ & 26,4 & 20,9 & 19 & 19,2 & 19,4 \\
\hline & Unemployment rate ( $\%$ of GDP) & 13,7 & 17,8 & 15,3 & 13,2 & 11,8 \\
\hline & $\begin{array}{r}\text { Unemployment, youth, total (\% } \\
\text { of total labor force ages } 15-24) \\
\text { national estimate(WDI-2) }\end{array}$ & 29,2 & 35,2 & 32 & 26,2 & 21,8 \\
\hline & $\begin{array}{l}\text { At risk of poverty rate by poverty } \\
\text { threshold age and sex }\end{array}$ & 20,3 & 20,5 & 19,2 & 18,6 & 20,6 \\
\hline \multirow[t]{3}{*}{ UK } & Unemployment rate ( $\%$ of GDP) & 7,8 & 7,9 & 7,8 & 8,0 & 7,5 \\
\hline & $\begin{array}{r}\text { Unemployment, youth, total (\% } \\
\left.\text { of total labor force ages } 15^{-24}\right) \\
\text { national estimate(WDI-2) }\end{array}$ & 19,1 & 19,6 & 20,1 & 21,3 & 20,2 \\
\hline & $\begin{array}{l}\text { At risk of poverty rate by poverty } \\
\text { threshold age and sex }\end{array}$ & 17,3 & 17,1 & 16,2 & 16 & 15,9 \\
\hline \multirow[t]{3}{*}{ Croatia } & Unemployment rate ( $\%$ of GDP) & 9,1 & 11,8 & 13,4 & 15,8 & 17,7 \\
\hline & $\begin{array}{r}\text { Unemployment, youth, total (\% } \\
\text { of total labor force ages 15-24) } \\
\text { national estimate(WDI-2) }\end{array}$ & 25,7 & 33,5 & 36,5 & 44,0 & $5^{1,5}$ \\
\hline & $\begin{array}{r}\text { At risk of poverty rate by poverty } \\
\text { threshold age and sex }\end{array}$ & 17,9 & 20,6 & 20,9 & 20,4 & 19,5 \\
\hline \multirow[t]{3}{*}{ Estonia } & Unemployment rate ( $\%$ of GDP) & 13,8 & 16,9 & 12,5 & 10,1 & 8,8 \\
\hline & $\begin{array}{r}\text { Unemployment, youth, total (\% } \\
\text { of total labor force ages } 15-24) \\
\text { national estimate(WDI-2) }\end{array}$ & 27,8 & 33,2 & 22,6 & 21 & 18,2 \\
\hline & $\begin{array}{r}\text { At risk of poverty rate by poverty } \\
\text { threshold age and sex }\end{array}$ & 19,7 & 15,8 & 17,5 & 17,5 & 18,6 \\
\hline \multirow[t]{3}{*}{ Germany } & Unemployment rate ( $\%$ of GDP) & 7,7 & 7,1 & 5,9 & 5,4 & 5,3 \\
\hline & $\begin{array}{r}\text { Unemployment, youth, total (\% } \\
\text { of total labor force ages 15-24) } \\
\text { national estimate(WDI-2) }\end{array}$ & 10,8 & 9,6 & 8,3 & 8,1 & 7,8 \\
\hline & $\begin{array}{r}\text { At risk of poverty rate by poverty } \\
\text { threshold age and sex }\end{array}$ & 15,5 & 15,6 & 15,8 & 16,1 & 16,1 \\
\hline
\end{tabular}

Source: Unemployment rate: $\underline{\text { http://data.worldbank.org/indicator/SL.UEM.TOTL.ZS?page=1 }}$ Unemployment, youth, total (\% of total labor force ages 15-24) national estimate: (WDI-2) http://data. worldbank.org/data-catalog/world-development-indicators/

At risk of poverty rate: Eurostat (European Commission); http://ec.europa.eu/eurostat/statisticsexplained/index.php/Income_distribution_statistics

Table 5 . show that in the period of 2009-2013 most countries (because of fiscal austerity policy, accompanied with recession and slump in economic activity) increased unemployment, especially in youth unemployment, which influence negatively on social hardship and risk of poverty ${ }^{2}$. In the period of 2009-2013 unemployment rate was: Portugal $(9,1-17,7)$, Italy $(7,8-12,2)$, Greece $\left(9,5^{-27}, 3\right)$, Spain $(18,1-26,6)$, Croatia $(9,1-17,7)$.

2 Poverty is measured by Indicator- Risk of poverty rate by poverty threshold age and sex (Eurostat). There are complications in establishing a nexus between fiscal austerity and poverty because of the difficulty in defining poverty. 
The percentage of unemployment youth rate were even bigger. For example, in 2013 the highest unemployment youth rate was in Greece with $58,4 \%$, Spain $57,2 \%$, and Croatia $5^{1,}, 5^{\%}$.

Other countries, with better financing and economic performance had a better result in employment and poverty also.

For example, in the period from 2009-2013 countries which decreased unemployment rate was: Latvia $(17,1-11,1)$, Lithuania $\left(13,7^{-11}, 8\right)$, UK $(7,8-7,5)$, Estonia $(7,8-7,5)$, Germany $\left(7,7^{-}, 5,3\right)$. The interesting fact is that the young unemployment rate in these countries was also higher. The most higher unemployment young rate was in Latvia and UK with $(20,2 \%)$ and the smallest in Germany with $7,8 \%$.

Finally, the progression on unemployment in the EU in the previous year has been remarkable and economic and social cost of fiscal adjustment has been very high.

The data analysis points to the problem of the structure of the Eurozone (significant variation in economy between the EU member states have followed a different path to austerity) and supporting the hypothesis that with eliminating the welfare state, we cannot achieve sustainable long time growth and decrease the deficit.

\section{CONCLUSION}

In most EU countries with shattered economy, with government debt still high and exceeding the threshold value of 60 percent of GDP, the big challenge in the future will be sustainable fiscal consolidation which supports long-term growth and employment as welfare state determinants.

Despite the ongoing debate and numerous studies, there is a lack of empirical investigation on the defining the methodology of austerity, especially in the social context. Due to no consensus about the implementation of fiscal austerity has been achieved. Therefore, until know, we do not have an answer to the questions when austerity is beneficial? Alternatively, "Should governments apply austerity despite their weak economies and diversity"?

The findings of these paper indicate that the important causes of deterioration of fiscal sustainability are neglecting the problem of diversity (structure of the Eurozone) and social implications for welfare. The main conclusion is that the emphasis should be placed on defining austerity methodology which will implement economic and social context.

The outcome of current research can serve as the basis for future research on the role of austerity in economic policy. 


\section{REFERENCES}

Afonso, A., Expansionary fiscal consolidations in Europe: new evidence, Applied Economics Letters, Vol.17, (2010):105-109

Alesina, A. and Ardagna, S., Tales of Fiscal Adjustments, Economic Policy, 13 (27), (1998): 489-585

Alesina, A. Perotti, R., Tavares, J., The Political Economy of Fiscal Adjustments, Brookings Papers on Economic Activity, No.1, (1998): 197-266

Alesina, A., Ardagna, S., Large changes in fiscal policy: taxes versus spending, Tax Policy and the Economy, Vol.24. 2010.

Alesina, A., Ardagna, S., Large changes in fiscal policy: Taxes versus spending, Tax Policy and the Economy 24, (2010): $35^{-68}$

Alesina, A., Perotti, R., Fiscal expansions and adjustments in OECD countries, Economic Policy, Vol.21, (1995): 207-24.8

Antokakis, N. Collins, A., The impact of fiscal austerity on suicide: on the empirics of a modern Greek tragedy, Social Science and Medicine 112, (2014):39-50

Arestis, P., Fiscal policy is Still an Effective Instrument of Macroeconomic Policy, Panoeconomicus,

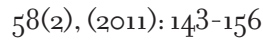

Arestis, P., Fiscal policy: a strong macroeconomic role, Review of Keynesian Economics, Innaugural Issue, (2012): 93-108

Arestis, P., Pelagidis, T., Absurd Austerity Policies in Europe, Challenge, Vol.53:6, (2010): 54-61

Auerbach, A. J. and Gorodnichenko, Y., Measuring the Output Responses to Fiscal Policy, American Economic Journal, Economic Policy, Vol.4, (2012): 1-27

Bilbao-Ubillos, J., Fernandez-Sainz, A.I., The impact of austerity policies in the Eurozone: fiscal multipliers and adjustment fatigue, Applied Economics Letters, Vol.21:14, (2014): 955-959

Blanchard, O.J., Perotti, R., "An Empirical Investigation of the Dynamic Effects of Changes in Government Spending and Revenues on Output", Quarterly Journal of Economics, (2002): 1329-1368

Blyth, M., Austerity: The History of a dangerous idea, Oxford University Press, USA, 2013.

Branas, C.C. Kastanaki, A.E., Michalodimitrakis, M., Tzougas, J., Kranioti, E.F., Theodorakis, P.N., Carr, B.G. and Wiebe, D.J. "The Impact of Economic austerity and prosperity events on suicide in Greece, A3o-Year Interrupted Time- Series- Analysis" (2015). BMJ open, DOI:10.1136/bmjopen-2014-005619.

Calcagno, A., Can austerity work? Review of Keynesian Economics, Inaugural Issue, (2012): 24-36

Caporale, G.M., Škare, M., Testing the linkages between output growth, inflation and employment growth: evidence from a panel vector autoregression, Transformations in Business and Economics, Vol.13, No.2 (32), (2014): 42-59

Caporale, G.M., Skare, S., Testing the linkages between output growth, inflation and employment growth: evidence from a panel vector autoregression, Transformation in Business and Economics, Vol.13, No.2 $(32),(2014): 42-59$

Chang, H.J., 23 Things they don't tell you about the capitalism, Penguin Group, England, 2011-

Christopher, S., Adam, D.L. , David, L. Bevan, Fiscal deficits and growth in developing countries", Journal of Public Economics 89 (2005): 571-597 
Crotty, J., The great austerity war: what caused the US deficit crisis and who should pay to fix it? Cambridge Journal of Economics, Vol.36, Issue 1, (2012): 79-104,

Dietrich, D., Knedlik, T., Lindner, A., Central and Eastern European countries in the global financial crisis: a typical twin crisis?, Post-Communist Economies, Vol.23, No.4, (2011): 415-432

Dunn, S., Was Galbraith Right? The Great Crash, 2008, and Galbraith's Prescience, Challenge, Vol.54, Issue 6, (2011): 41-60

Edminston, D., The Age of Austerity: Contesting the Ethical Basis and Financial Sustainability of Welfare Reform in Europe, Journal of Contemporary European Studies, Vol.22, No.2, (2014): 118-131

Fontana, G. , Sawyer, M., Fiscal Austerity, Challenge, Vol. 54:2, (2011): 42-60

Galbraith, J.K., The end of Normal, New York, Simon and Shuster, 2014.

Hannsgen, G., Papadimitrou, D.B., Fiscal traps and macro policy after the Eurozone crisis, Public Policy Brief, No.127, 2012.

Hein, E. and Truger, A., Fiscal Policy and Rebalancing in the Euro Area: A Critique of the German Debt Brake from a Post-Keynesian Perspective, Vol.1, Special Issue, (2014): 21-38

Jayadev, A., Konczal, M., When is Austerity Right? In Boom, Not Bust, Challenge, Vol.53:6, (2010): 37- $5^{3}$

Jurčić, Lj., Hrvatska-oporavak ili stagnacija, Ekonomski pregled 64,(6), (2013): 671-68o

Kitromilides, Y., Deficit reduction, the age of austerity, and the paradox of insolvency, Journal of Post Keynesian Economics, Vol.33:3,(2011): $517^{-} 5^{36}$

Kitson, M, Martin, R., Tyler, P., The geographies of austerity, Cambridge Journal of Regions, Economy and Society, Vol4,(3), (2011): 289-302

Konzelmann, S. J., The Economics of Austerity, Centre for Business Research, University of Cambridge, Working Paper No. 4,34, 2012.

Krugman, P., End This Depression Now, N.Y. London, W.W. Norton and Company, 2012.

Matsaganis, M., Leventi, C., The Distributional Impact of Austerity and the Recession in Southern Europe, South European Society and Politics, Vol.19, No. 3, (2014): 393-412

Mc Kee, M. Karanikolos, M, Belcher, P, Stuckler, D., Austerity: a failed experiment on the people of Europe, Vol.12, no.4, (2012): 34,6-350

Minsky, H.P., Stabilizing an Unstable Economy, MacGraw Hill, 2008.

Mosley, P. et.al., The Politics of Poverty Reduction, Oxford University Press, Oxford, 2011.

Noell, E.S., Smith, S.L.S., Webb, B.G., Economic Growth, Unleashing the potential of human flourishing, AEI Press, Washington, D.C., 2013.

Overmans, J.F.A., Noordegraaf, M., Managing austerity: rhetorical and real responses to fiscal stress in local government, Public Money and Management, Vol. 34:2, (2014): 99-106

Palley, T., Europe's financial crisis, in Bresser-Pereira, L.C., Kregel, J., Burlamaqui, L. (2014), Financial Stability and Growth, London and New York, Routledge Taylor and Francis Group, (2014): $100-105$

Partridge, M., Weinstein, A.L., Rising Inequality in an Era of Austerity: The Case of the US, European Planning Studies, Vol.21, No.3, (2013): 388-410

Perotti, R., Fiscal Consolidation in Europe, Composition Matters, The American Economic Review, Vol.86, No.2, Papers and Proceedings of the Hundredth and Eighth Annual Meeting of the American 
Economic Association San Francisco, CA, (1996): 105-110

Pollin, R., Austerity is Not a Solution, Challenge, Vol.53:6, (2010): 6-36

Radulescu, M., Druica, E., The impact of fiscal policy on foreign direct investments. Empiric evidence from Romania, Economic Research, Vol.27, No.1, (2014): 86-106

Romer, G., Fiscal Policy in the Crisis: Lessons and Policy Implications, University of California, Berkley, Department of Economics, 2012.

Romer, C.D. and Romer, D.H., The macroeconomic effects of tax changes estimates based on a new measure of fiscal shocks, American Economic Review, vol.100, no.3, (2010): 763-801

Sever,I., Drezgić S., Blažić H., Budget spending and economic growth in Croatia, Zbornik radova Ekonomski Fakultet Rijeka, Vol.29, sv.2, (2011): 291-331

Shakina, E., Barajas, A., The dynamic of intellectual resources during the economic crisis, Economic Research, Vol.27, No.1, (2014): 861-881

Šimović, H., Ćorić, T., Deskar-Škrbić, M. (2014), Mogućnosti i ograničenja fiskalne politike u Hrvatskoj, Ekonomski pregled 65 (6), (2014): 541-575

Škare, M., Pržiklas Družeta, R., Fiscal Austerity Versus Growth in Croatia, Contemporary Economics, Vol.9, No.1, (2015): 77-92

Stiglitz, J., The Price of Inequality, New York, London, W.W. Norton and Company, 2013.

Štreimikiene, D., Baležentis, A., Integrated sustainability index: The case study of Lithuania, Intelectual Economics, Vol7, No.3 (17), (2013):289-3०3

Stuckler, D., Basu, S., The Body Economic: Why Austerity Kills, London, Basic Books, 2013.

Szalkolcai, G., The triple deficit of Hungary, Hungarian Statistical review, Vol.10. (2006): 40-62

Zavadskas, K.A., Kelpsiene, A.B.L., Kutut, D.B.V., Conceptual modeling of construction and real estate crisis with emphasis on comparative qualitative aspects description, Transformation in Business and Economics, Vol.9, No1 (19), (2010): 42-61

Zezza, G., The impact of fiscal austerity in the Eurozone, Review of Keynesian Economics, Inaugural Issue, (2012): $37^{-} 54$

http://ec.europa.eu/eurostat/tgm/table.do?tab=table\&init=1\&language=en\&pcode=tecoo11 $\&$ plugin=1 http://ec.europa.eu/eurostat/tgm/table.do?tab=table\&init=1\&language=en\&pcode=teco0021\&plugin=1 http://appsso.eurostat.ec.europa.eu/nui/show.do?dataset=gov_10amain\&lang=en http://ec.europa.eu/eurostat/tgm/table.do?tab=table\&init=1\&language=en\&pcode=teina225\&plugin=1 http://ec.europa.eu/eurostat/tgm/printTable.do?tab=table\&plugin=1\&language=en\&pcode=tecoooog\& printPreview=true

http://ec.europa.eu/eurostat/tgm/printTable.do?tab=table\&plugin=1\&language $=$ en\&pcode=tecooolo\& printPreview=true

http://ec.europa.eu/eurostat/tgm/printTable.do?tab=table\&plugin=1\&language=en\&pcode=tecooo11\&p rintPreview=true http://data.worldbank.org/indicator/NE.IMP.GNFS.ZS

http://data.worldbank.org/indicator/NE.EXP.GNFS.ZS/countries 
http://data.worldbank.org/indicator/SL.UEM.TOTL.ZS?page=1

http://data.worldbank.org/data-catalog/world-development-indicators/

http://ec.europa.eu/eurostat/statistics-explained/index.php/Income_distribution_statistics 
